\title{
Salmonella sp. and Shigella sp.in House Flies in Jatinangor
}

\section{Reemarachna Poravi, ${ }^{1}$ Ramlan Sadeli, ${ }^{2}$ Berlian Isnia Fitrasanti, ${ }^{3}$ Sunaryati Sudigdoadi ${ }^{2}$} ${ }^{1}$ Faculty of Medicine, Universitas Padjadjaran, ${ }^{2}$ Department of Microbiology, Faculty of Medicine, Universitas Padjadjaran, ${ }^{3}$ Department of Forensics and Medicolegal, Faculty of Medicine, Universitas Padjadjaran/Dr. Hasan Sadikin General Hospital, Bandung

\begin{abstract}
Background: Diarrhea is a common problem in Indonesia and mostly caused by pathogenic bacteria such as Salmonella sp. and Shigella sp., transmitted by house flies. The incidence of acute diarrhea has been rising over the years. The aim of this study is to determine if Salmonella sp. and Shigella sp. can be found in house flies in Jatinangor.

Methods: A descriptive study was done, involving 20 samples of house flies caught from houses and street vendors in Jatinangor during the period of March 2012 to January 2013. Bacteria were isolated from house flies and identified using various biochemical tests.

Results: Shigella sp. was isolated from $5 \%$ of the house flies caught in Jatinangor. The house flies caught from the street vendors revealed a higher percentage of bacteria than those caught from houses.

Conclusion: Only Shigella sp. can be isolated from house flies in Jatinangor. However, a small percentage of Shigella sp. was also found from the house flies captured around Jatinangor. [AMJ.2014;1(1):17-20]
\end{abstract}

Keywords: house flies, Salmonella sp., Shigella sp.

\section{Salmonella sp. dan Shigella sp. pada Lalat Rumah di Jatinangor}

\begin{abstract}
Abstrak
Latar Belakang: Di Indonesia, diare merupakan masalah kesehatan yang sering terjadi dan sebagian besar disebabkan oleh bakteri pathogen seperti Salmonella sp. and Shigella sp yang terdapat pada lalat rumah. Angka kejadian diare akut terus meningkat dari tahun ke tahun. Tujuan dari penelitian ini adalah untuk menemukan bakteri Salmonella sp. dan Shigella sp. pada lalat rumah di Jatinangor.

Metode: Penelitian ini merupakan penelitian deskriptif yang melibatkan 20 sampel lalat rumah yang ditangkap dari rumah dan pedagang kaki lima (PKL) di Jatinangor selama periode Maret 2012-Januari 2013. Bakteri diisolasi dari lalat rumah dan diidentifikasi dengan menggunakan berbagai tes biokimia.

Hasil: Shigella sp. diisolasi dari 5 \% lalat rumah yang tertangkap di Jatinangor . Lalat rumah yang ditangkap dari PKL mempunyai persentase yang lebih tinggi daripada bakteri yang ditangkap dari rumah.

Simpulan: Hanya Shigella sp. yang dapat diisolasi dari lalat rumah di Jatinangor. Sebagian kecil dari Shigella sp. juga ditemukan dari lalat rumah yang ditangkap di sekitar Jatinangor.

Kata kunci: lalat rumah, Salmonella sp , Shigella sp
\end{abstract}

\section{Introduction}

Incidence of acute diarrhea and typhoid has been rising over the years. In Indonesia, diarrhea is indeed a major public health concern. ${ }^{1-4}$ This is supported with the fact that Indonesia is among one of the few countries with low sanitation and food hygiene levels. ${ }^{4}$ Apart from that, diarrhea cases among medical students studying in Indonesia are identified every year.

Salmonella sp. and Shigella sp. accounts for most of the diarrhea cases that occur worldwide. ${ }^{3,5}$ Muscadomestica or house fly is known to be a potent vector in transmitting

Correspondence: Reemarachna Poravi, Faculty of Medicine, Universitas Padjadjaran, Jalan Raya Bandung-Sumedang Km.21, Jatinangor, Sumedang, Indonesia, Phone : 08170209211, Email : reema_pillay@hotmail.com 
these pathogenic bacteria. ${ }^{6}$ However, whether the house fly is a potent vector in transmitting these bacteria in Jatinangor is still questionable.

This research is conducted to determine if Salmonella sp. and Shigella sp. can be isolated from house flies in Jatinangor. The results of this research will serve as an additional knowledge and can be used as a guide for defining preventive measures to be taken.

\section{Methods}

This is a descriptive study involving 20 samples of house flies caught from houses and street vendors in Jatinangor during the period of March 2012 to January 2013. Twenty house flies were caught around Jatinangor using an electric net and used as sample.

The common places where house flies can be easily found namely houses and street vendors were included as the source of sample collection. Injured house flies were excluded from the study. The house flies caught were then soaked in tryptic soy broth (TSB) and were incubated at $37^{\circ} \mathrm{C}$ for a day. ${ }^{7-9} \mathrm{As}$ for the bacterial isolation, the solution used for soaking the house flies was cultured on Mac Conkey agar. The agar was incubated at $37^{\circ} \mathrm{C}$ for 24 hours. ${ }^{9,10}$ After one day, the colonies that were streaked on the Mac Conkey agar were analyzed and the non-lactose fermented colonies were distinguished from the lactose fermented ones. The non-lactose fermented colonies were stained using Gram staining
Table 1 Percentage of Sample with Positive Results for Different Tests by Place

\begin{tabular}{lcc}
\hline & $\begin{array}{c}\text { House Flies } \\
\text { Caught in } \\
\text { Houses (n=10) }\end{array}$ & $\begin{array}{c}\text { House Flies } \\
\text { Caught in } \\
\text { Street Vendors } \\
\text { (n=10) }\end{array}$ \\
\hline Lactose & 0 & $10 \%$ \\
Gas & $80 \%$ & $60 \%$ \\
H2S & $10 \%$ & $10 \%$ \\
Mobility & $90 \%$ & $70 \%$ \\
Indole & $50 \%$ & $40 \%$ \\
Urease & $70 \%$ & $40 \%$ \\
Citrate & $70 \%$ & $80 \%$ \\
\hline
\end{tabular}

to identify Gram negative rods. Various biochemistry tests such as Kligler Iron Agar (KIA), Motility, Indole and Urease (MIU) agar and Citrate agar were performed on the samples that revealed Gram negative rods. The results were interpreted and a comparison on the bacteria species found were made between the samples of house flies caught from houses and street vendors. ${ }^{9,10}$

\section{Results}

The majority of the bacteria isolated from the house flies show lactose negative results (Table 1). Eighty percents of the samples

Table 2 Identification of the Bacteria by Biochemical Test Results

\begin{tabular}{clll}
\hline $\begin{array}{l}\text { Samples Caught from } \\
\text { Houses }\end{array}$ & Bacteria & $\begin{array}{l}\text { Samples Caught from } \\
\text { Street Vendors }\end{array}$ & Bacteria \\
\hline 1 & Shigella sp. & A & Providenciarettgeri \\
2 & Providenciarettgeri & B & Proteus mirabilis \\
3 & Proteus mirabilis & C & Proteus vulgaris \\
4 & Serratia sp. & D & No Gram negative bacteria \\
5 & Proteus mirabilis & E & Serratia sp. \\
6 & Providenciarettgeri & F & Enterobacter cloacae \\
& & & \\
7 & Serratia sp. & G & Klebsiellaoxytoca \\
8 & Proteus vulgaris & H & Hafniaalvei \\
9 & Providenciarettgeri & I & Proteus vulgaris \\
10 & Providenciarettgeri & J & Serratia sp. \\
\hline
\end{tabular}


caught from houses and $60 \%$ of the samples caught from street vendors revealed positive gas test.

Most of the bacteria present in the samples caught from houses showed a higher percentage for mobility and indole and urease productions compared to those caught from street vendors. Furthermore, the samples of house flies caught from street vendors revealed a higher percentage of bacteria that generate energy from citrate, thus exhibit a positive result.

The interpretation of the results from the biochemical tests was matched accordingly to identify the bacteria. The various types of bacteria found in each sample of house flies caught (Table 2).

\section{Discussion}

Based on the results of this study, there were many types of enteric bacteria found in Jatinangor. The percentages of Salmonella sp. and Shigella sp. found were 5\% and $0 \%$ respectively. The other samples from the same set of house flies caught revealed 25\% of Providenciarettgeri, $20 \%$ of Serratia sp., $15 \%$ of Proteus mirabilis, $15 \%$ of Proteus vulgaris, $5 \%$ of Enterobacter cloacae, 5\% of Klebsiellaoxytoca and 5\% of Hafniaalvei. Only one of the 20 samples revealed no Gram negative bacteria.

These results may be less satisfactory because of the short study time. Salmonella sp. has the potential of infecting house flies during the later stages of adult house flies' life. This could probably be a reason why no Salmonella sp. was found. This finding is similar to the findings of a research that involved isolating Salmonella sp. from house flies for 5 years. ${ }^{11,12}$ Furthermore, a small sample size were used in this study due to the limited time when larger sample sizemay yield highly positive results for the bacteria isolated from the house flies due to a higher number of bacteria isolated. ${ }^{11}$

There is also a possibilitythat the bacteria present in the house flies were killed by the electricity produced by the electric net during sample collection activity. However, this fact is still unknown and it is considered to be a study limitation.

In comparison with a study done in Malaysia, the identification of bacteria found in both studies is roughly the same.9This could be due to the similarity ingeographical location between Malaysia and Indonesia. Moreover, another study done in Iran revealed that the highest proportion of bacteria found was Escherichia coli (36.5\%) and Proteus sp.(14.8\%). The study also revealed that there were not many Enterobacteriaceae found.13In comparisons with this study, Proteus covers about $30 \%$ of the entire samples. The varied results may probably due to the differences in geographical location, climate and temperature.

Providenciarettgeri, Serratia sp. and Proteus sp. are known to cause urinary tract infections in humans. Proteus sp., Enterobacter cloacae and Klebsiellaoxytocainhabit the human intestinal tract, but they may travel to other organs or structures causing other diseases. Hafniaalvei is rarely considered to be pathogenic. ${ }^{14}$

Among the 20 house flies caught as sample, one sample revealed that there were only lactose fermented colonies present. This result does not prove or conclude that there are no pathogenic bacteria found, as the lactose fermented colonies may consist of pathogenic bacteria.

From Table 2, it can be proven that there are more bacteria isolated from the house flies caught from street vendors than the ones caught from houses around Jatinangor. Therefore, an assumption can be made based on this finding that street vendors are generally not a safe place to eat and measures are required to educate people on actions such as proper hand washing technique before and after meal, make sure that the food should be fresh and not prepared long beforehand.

\section{References}

1. Yusmidiarti. Environmental health facilities and women behavior and diarrhea incidence in under five in work area of Pasar Ikan Community Health Center, Teluk Segara Subdistrict, Bengkulu Municipality, in 2010 [thesis].Yogyakarta: Gadjah Mada University; 2011.

2. Farthing $M$, Lindberg G, Dite $P$, Khalif $I$, Salazar-Lindo E, Ramakrishna BS, et al. World Gastroenterology Organisation practice guideline: acute diarrhea. Milwaukee: World Gastroenterology Organisation; 2008.

3. Simpson E, Wittet S, Bonilla J, Gamazina $\mathrm{K}$, Cooley L, Winkler JL. Use of formative research in developing a knowledge translation approach to rotavirus vaccine introduction in developing countries. BMC Public Health. 2007;7:281. 
4. Fening KO, Edoh DA. The impact of socioeconomic status and sanitation levels on the prevalence of diarrheal diseases in the Akim Oda area of Ghana. The Internal Journal of Epidemiology [Online Journal] 2009 [cited 2012 July 26].Available from: http://www.ispub.com/

5. Ogg B, Cochran S. Flies in the home. Lincoln: University of Nebraska-Lincoln Extension Lancaster County; 2012 [cited 2012 June 26]; Available from: http://lancaster.unl. edu/pest/resources/flies015.shtml.

6. Townsend L. Entfact-506: how far can house flies fly? Department of Entomology, College of Agriculture, Food and Environment, University of Kentucky; 2010 [cited 2012 July 29]; Available from: http://www2.ca.uky.edu/entomology/ entfacts/ef506.asp

7. Ngan V. Maggot debridement therapy. New Zealand: DermNet NZ; 2005; [cited 2012 July 26]; Available from: http://dermnetnz. org/procedures/maggots.html.

8. Collier R. New interest in maggot therapy. CMAJ. 2010;182(2):E121-2

9. Nazni WA, Seleena B, Lee.HL, Jeffery J, TRogayah TA, Sofian MA. Bacteria fauna from the house fly, Muscadomestica (L.).
Trop Biomed. 2005;22(2):225-31.

10. Butler JF, Garcia-Maruniak A, Meek F, Maruniak JE. Wild florida house flies (Muscadomestica) as carriers of pathogenic bacteria. Florida Entomologist. 2010;93(2):218-23

11. Durham S. Shoo Fly! Roke of house flies in spreading Salmonella in poultry. Agricultural Research Magazine. 2008; 56(3):22

12. Uesugi AR, Danyluk MD, Mandrell $\mathrm{RE}$, Harris LJ. Isolation of Salmonella Enteritidis phage type 30 from a single almond orchard over a 5-year period. J Food Prot. 2007;70(8):1784-9.

13. Lowe C, Willey B, O'Shaughnessy A, Lee W, Lum M, Pike K, et al. Outbreak of extended-spectrum $\quad \beta$-lactamaseproducing Klebsiellaoxytoca infections associated with contaminated hand washings inks. Emerg Infect Dis. 2012; 18(8):1242-7.

14. Podschun R, Fischer A, Ullmann U. Characterisation of Hafniaalvei isolates from human clinical extra-intestinal specimens: haemagglutinins, serum resistance and siderophore synthesis. J Med Microbiol. 2001;50(3):208-14. 